\title{
Estimation of Solar Energy Using Different Empirical Models at Mid Hill, Nepal
}

\author{
U. Joshi, P. M. Shrestha, S. Maharjan, B. Maharjan, \\ N. P. Chapagain, I. B. Karki and K. N. Poudyal
}

Journal of Nepal Physical Society

Volume 7, Issue 2, June 2021

ISSN: 2392-473X (Print), 2738-9537 (Online)

Editors:

Dr. Binod Adhikari

Dr. Bhawani Joshi

Dr. Manoj Kumar Yadav

Dr. Krishna Rai

Dr. Rajendra Prasad Adhikari

Mr. Kiran Pudasainee

JNPS, 7 (2), 42-48 (2021)

DOI: https://doi.org/10.3126/jnphyssoc.v7i2.38621

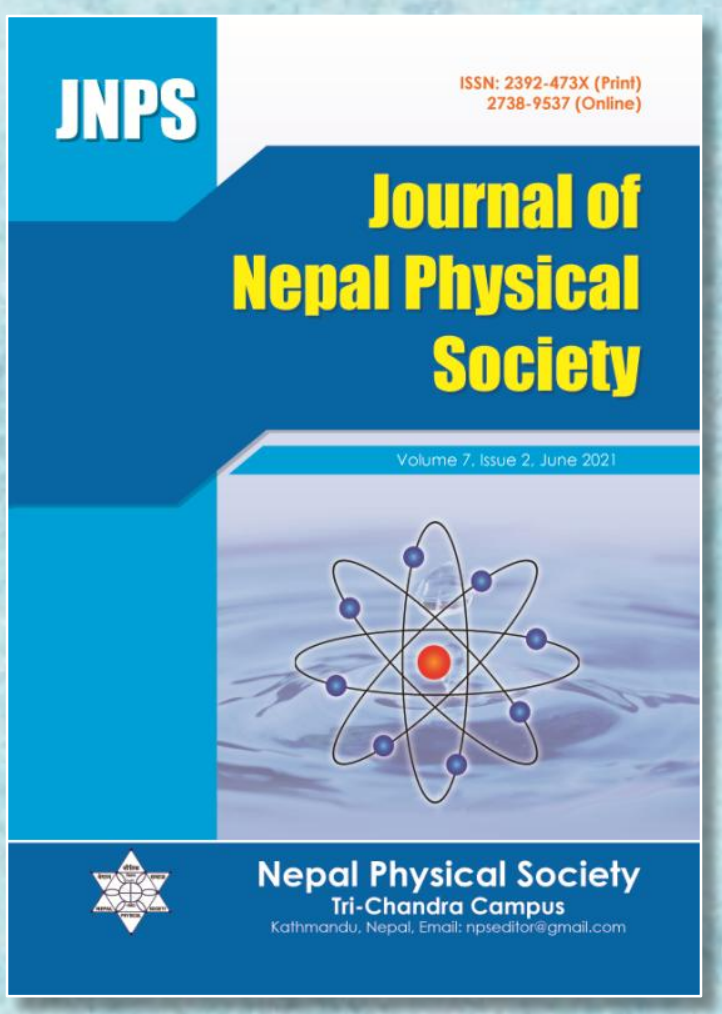

Published by:

Nepal Physical Society

P.O. Box: 2934

Tri-Chandra Campus

Kathmandu, Nepal

Email: nps.editor@gmail.com 


\title{
Estimation of Solar Energy Using Different Empirical Models at Mid Hill, Nepal
}

\author{
U. Joshi ${ }^{1,2, ~ *, ~ P . ~ M . ~ S h r e s t h a ~}{ }^{1}$, S. Maharjan ${ }^{3}$, B. Maharjan ${ }^{4}$, \\ N. P. Chapagain ${ }^{5}$, I. B. Karki ${ }^{1,6}$ and K. N. Poudyal ${ }^{7}$ \\ ${ }^{1}$ Department of Physics, Patan Multiple Campus, Tribhuvan University, Patan, Nepal \\ ${ }^{2}$ Central Department of Physics, Tribhuvan University, Kirtipur, Nepal \\ ${ }^{3}$ Department of Hydrology and Meteorology, Government of Nepal \\ ${ }^{4}$ United Nations World Food Programme (UNWFPA), Patan, Nepal \\ ${ }^{5}$ Department of Physics, Amrit Campus, Tribhuvan University, Kathmandu, Nepal \\ ${ }^{6}$ Nepal Open University, Kathmandu, Nepal \\ ${ }^{7}$ Department of Applied Sciences, Pulchowk Campus, IOE, Tribhuvan University, Patan, Nepal \\ *Corresponding Email: ushajoshik1967@gmail.com, usha.joshi@pmc.tu.edu.np
}

Received: 15 April, 2021; Revised: 13 May, 2021; Accepted: 25 June, 2021

\begin{abstract}
Accurate knowledge of global solar radiation distribution is essential for designing, sizing, and performing an evaluation of solar energy system in any part of the world. However, it is not available in many sites of Nepal due to the high expense of the technical process. This study is focused on the performance of different models based on daily global solar radiation, sunshine hour, temperature, and relative humidity at mid-hill region Lumle, (lat. $28.2965^{\circ} \mathrm{N}$, long. $83.8179^{\circ} \mathrm{E}$, and Alt. 1740.0 m.a.s.1.). This study is carried for the year 2018 to 2020 . The performance of different models based on sunshine hour, temperature, and relative humidity were analyzed using the regression technique and statistical tools such as Root Mean Square Error (RMSE), Mean Bias Error (MBE), Mean Percentage Error (MPE), and Coefficient of determination $\left(\mathrm{R}^{2}\right)$. After the analysis, the modified Angstrom model (M-9) based on temperature difference and relative humidity was found to be the best in terms of accuracy of least RMSE value and highest coefficient of determination. Finally, the empirical constants for model $\mathrm{m}-9$ are $\mathrm{a}=0.003, \mathrm{~b}=0.523, \mathrm{c}=0.118$ and $\mathrm{d}=0.002$ obtained. The calculated empirical constants can be utilized for the prediction of GSR at similar geographical locations of Nepal.
\end{abstract}

Keywords: Global Solar Radiation, Sunshine hours, Regression technique, Empirical constants, Statistical tools.

\section{INTRODUCTION}

The sun has ample energy which is vital for the existence of human life as well as creatures on the earth. Solar energy is obtained by the thermonuclear fusion process that converts about $5 \times 10^{6}$ tons of hydrogen every second [1]. The solar energy transmitted as global solar radiation on the earth surface is considerably affected by meteorological parameters such as relative humidity, temperature, water vapour, clouds, ozone, aerosols, etc. on passing through the earth's atmosphere [2, 3]. Clouds are the key factor affecting solar radiation [4]. Global solar radiation is also affected by geographical parameters such as solar zenith angle, altitude, latitude, longitude, day length, declination, and local weather condition [5]. Cloud directly relates with bright sunshine hours which also affects solar radiation. Temperature also influences solar radiation so; solar radiation is more in summer than winter [4].

In Nepal, $83 \%$ of the total population lives in rural areas [6]. Many people have no access to modern form of energy like electricity, petroleum products, and renewable energy sources. Even in this 
developed world, about $83.7 \%$ of total energy consumption in Nepal if fulfilled from traditional energy resources such as fuel, wood, agriculture residue, and cattle dung which are used for cooking and heating purposes in rural areas [7]. Solar energy is used as an alternative source of energy. It is the largest renewable resource on the earth. It can be converted into useful energy with the help of photovoltaic cells which can generate electricity. The implementation of solar as well as other alternative sources of energy helps to gain quality life and prevent environmental degradation $[8,9]$. So, the estimation of solar energy potential at the measuring site will be essential for modern agriculture, study about climate change, hydrology, environmental studies, solar energy system, and other applications $[10,11]$.

Furthermore, daily data of solar radiation as well as other meteorological parameters are the essential for estimation of long-term solar system performance. The availability of these data at every location is minimal due to the cost, maintenance, and calibration requirement of the measuring equipment [12]. In locations where no measured values are available, a common application has been to determine this parameter by appropriate correlations which are empirically established using measured data.

In addition, the most commonly used parameter for estimating global solar radiation is sunshine radiation. Angstrom [13] proposed the linear relationship between the ratios of daily average global solar radiation to the corresponding value on a completely clear day and relative sunshine hour (ratio of sunshine duration to the maximum possible sunshine duration). It was modified by Prescott using extraterrestrial solar radiation instead of clear sky radiation [14]. Models can be used to estimate and predict GSR where measurements are not available. There are several models that has been used to calculate solar radiation using easily available meteorological parameters and climatological parameters such as sunshine hour [8, $15,16,17]$, temperature $[18,19,20,21]$, latitude $[22,23]$, relative humidity $[24,25]$, rainfall [26] and cloudiness [27]. In Nepal, the estimation of GSR, using empirical models and RadEst v3.0 software were observed [28]. The available literature shows that limited studies have been conducted in Nepal related to solar radiation due to the scarcity of solar radiation data and lack of research culture. That is why it is necessary to develop authentic empirical constants based on meteorological parameters such as temperature, sunshine hour, and relative humidity. In addition, the empirical constants should be developed for every $200 \mathrm{~m}$ altitude because of abruptly varying geographical structure, ecology and climate [29].

The objective of this study was to evaluate various models for the estimation of the daily average hourly global solar radiation on the horizontal surface from the bright sunshine hour, temperature, and relative humidity and to select appropriate models for Lumle. The process is followed by the linear regression technique used to develop a reductive model. Then, the estimated daily average hourly GSR is statistically compared to the measured data obtained for an even site.

\section{METHODS AND INSTRUMENTATION}

\section{Site Location}

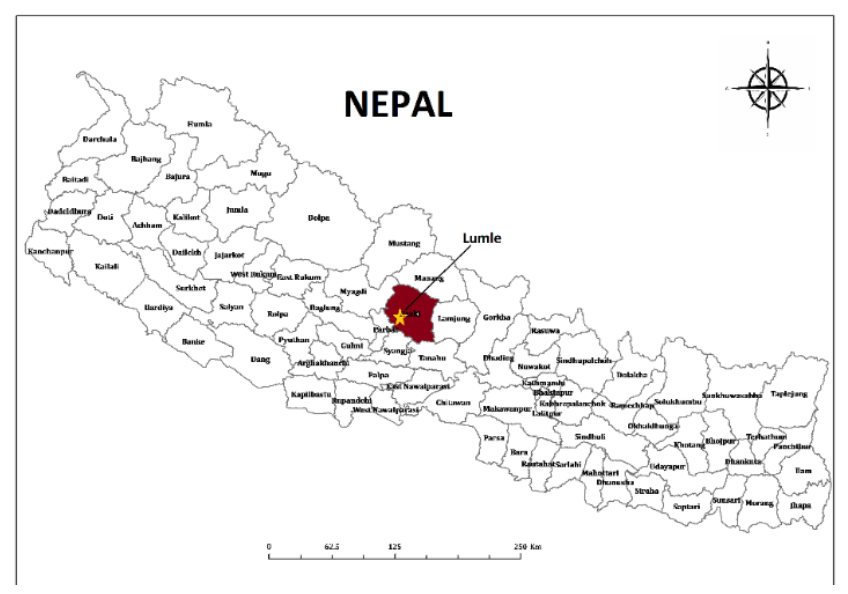

Fig. 1: Study site Mid Hill (Lumle), Nepal [31]. (Source: Survey Department, GoN, 2020)

Nepal lies on the most favorable range of solar energy on the global map. Lumle (lat. $28.2965^{\circ} \mathrm{N}$, long. $83.8179^{\circ} \mathrm{E}$, and Alt. 1740 masl) is a sub-urban and Village Development Committee in Kaski, Gandaki province. Lumle VDC has situated $32 \mathrm{~km}$. west from Pokhara on Pokhara-Baglung Highway. It is about an hour's drive from the Pokhara, Kaski. This site is lying in the subtropical region, where it receives the highest precipitation $(5500 \mathrm{~mm}$ per year) in Nepal, with a subtropical highland climate with mild, very wet summers, and cold, fairly dry winters [30].

The daily data of GSR, sunshine hours, relative humidity, rainfall, and maximum \& minimum temperature on the horizontal surface was collected from the Alternate Energy Promotion Centre, (AEPC), Government of Nepal, and collaborative 
partner of World Bank Group, Department of Hydrology and Meteorology Government of Nepal, for the year 2018-2020 of Lumle. To measure the radiation data on the ground surface, CMP21pyranometer is used. CS215 Campbell Scientific is used to measure temperature and relative humidity. 52203 R M Young Tipping bucket rain gauge is used to measure rainfall [32]. According to the study of different literature reviews, the empirical models in Table 1 could be viable for the estimation of empirical constants at the measuring site.

Table 1: List of models used

\begin{tabular}{lll}
\hline Model & Symbol & Relation \\
\hline Angstrom-Prescott Model & M-1 & $\frac{H_{g}}{H_{o}}=a+b\left(\frac{n}{N}\right)$ \\
Garica model (1994) & M-2 & $\frac{H_{g}}{H_{o}}=a+b\left(\frac{\Delta T}{N}\right)$ \\
Swarthman- Oguniade Model & M-3 & $\frac{H_{g}}{H_{o}}=a+b\left(\frac{n}{N}\right)+c(R H)$ \\
Modified Angstrom Model & M-4 & $\frac{H_{g}}{H_{o}}=a+b\left(\frac{n}{N}\right)+c(\Delta \mathrm{T})$ \\
Modified Angstrom Model & M-5 & $\frac{H_{g}}{H_{o}}=a+b\left(\frac{n}{N}\right)+c\left(T_{1}\right)$ \\
Olomiyesan-Oyedum Model & M-6 & $\frac{H_{g}}{H_{o}}=a+b\left(\frac{n}{N}\right)+c\left(\frac{\Delta T}{N}\right)$ \\
Abdalla model & M-7 & $\frac{H_{g}}{H_{o}}=a+b\left(\frac{n}{N}\right)+c\left(T_{1}\right)+d(R H)$ \\
Modified Angstrom (new)Model & M-8 & $\frac{H_{g}}{H_{o}}=a+b\left(\frac{n}{N}\right)+c(\Delta T)+d(R H)$ \\
Modified Angstrom (new)Model & M-9 & $\frac{H_{g}}{H_{o}}=a+b\left(\frac{n}{N}\right)+c\left(\frac{\Delta T}{N}\right)+d(R H)$ \\
\hline
\end{tabular}

\section{Extraterrestrial Radiation}

The extraterrestrial global solar radiation $\left(\mathrm{H}_{\mathrm{o}}\right)$ can be calculated from the following equations, [33],

$$
\begin{gathered}
H_{o}=\frac{24}{\pi} I_{s c}\left[1+0.033 \cos \left(\frac{360 \mathrm{n}_{d}}{365}\right)\right] \\
{\left[\cos \emptyset \cos \delta \sin \omega+\frac{\pi}{180} \omega \sin \emptyset \sin \delta\right] \ldots(1}
\end{gathered}
$$

Where,

$\mathrm{I}_{\mathrm{sc}}$ is the solar constant $\left(=1367 \mathrm{~W} \mathrm{~m}^{-2}\right)$,

$\emptyset=$ the latitude of the site ( $\mathrm{rad})$,

$\Delta=$ the solar declination (rad),

$\Omega=$ the mean sunrise hour angle for the given month, and

$\mathrm{n}_{\mathrm{d}}=$ the Julian day number of the year starting from the first of January.
The solar declination $(\delta)$ and the mean sunrise hour angle $(\omega)$ can be calculated by the following equations.

$$
\begin{gathered}
(\delta \text { degree })=23.45 \sin \left[\frac{360}{365}\left(284+n_{d}\right)\right] \ldots \\
\omega=\cos ^{-1}(-\tan \emptyset \tan \delta) \ldots(3)
\end{gathered}
$$

The relation of the day length is

$$
N=\frac{2}{15} \omega=\frac{2}{15} \cos ^{-1}(-\tan \emptyset \tan \delta) \ldots
$$

\section{Statistical Approach}

In this research work, the data of one-minute interval of daily solar radiation, maximum temperature, minimum temperature, relative humidity, and rainfall for the station at Lumle were 
obtained from Alternate Energy Promotion Center (AEPC) and World Bank during years 2018-2020. The conversion of data from one-minute interval format to the daily average of different parameters was performing by using Python programming language. The daily average hourly extraterrestrial radiation and day length were evaluated using the equations mentioned above. The values of empirical constants are found in different models using regression technique and then estimated values of global solar radiation were calculated. The performance of different models was evaluated based on statistical tools like Root Mean square error (RMSE), Mean percentage error (MPE), Mean bias error (MBE), and Coefficient of determination $\left(\mathrm{R}^{2}\right)$. These statistical tools are defined as follows [12].

$$
\begin{aligned}
& R M S E=\sqrt{\frac{1}{-} \sum_{i=1}\left(H_{i, c}-H_{i, m}\right)^{2}}\left(\mathrm{MJ} / \mathrm{m}^{2} / \text { day }\right) \ldots(5) \\
& M B E=\frac{1}{-} \sum_{i=1}\left(H_{i, c}-H_{i, m}\right) \quad\left(\mathrm{MJ} / \mathrm{m}^{2} / \text { day }\right) \ldots(6) \\
& M P E=\frac{1}{-}\left[\sum_{i=1}\left(\frac{H_{i, c}-H_{i, m}}{H_{i, m}}\right) \times 100\right](\%) \ldots(7) \\
& R^{2}=\left\{-\frac{1}{-} \sum_{i=1} \frac{\left(H_{i, m}-\overline{H_{m}}\right)\left(H_{i, c}-\overline{H_{c}}\right)}{\sigma_{m} \cdot \sigma_{c}}\right\}^{2} \ldots(8)
\end{aligned}
$$

Where, $\mathrm{H}_{\mathrm{i}, \mathrm{m}}$ is measured value, $\mathrm{H}_{\mathrm{i}, \mathrm{c}}$ is estimated value, is the number of data, $\overline{H_{m}}$ is the average of measured solar radiation, $\overline{H_{c}}$ is the average of estimated solar radiation.

\section{RESULTS AND DISCUSSION}

The empirical constants for different models are determined by using the linear regression analysis technique for the years 2018 through 2020, which is given in Table 1. The performance of the models is evaluated by using four statistical tools i.e., MBE, RMSE, MPE, and coefficient of $\mathrm{R}^{2}$ which are listed in Table 1 for the given models. The lower value of MBE, RMSE, and MPE and higher value of $R^{2}$ signify the reliability of a model. The coefficient of determination provides the proportion of variance in the dependent variable that can be explained by the independent variable. That means it tells how well the data fit the model. MBE provides the longterm performance of examined regression captures the average bias in the estimated and the observed GSR. The mean percentage error (MPE) is the computed average of percentage errors by which forecasts of a model differ from actual values of the quantity being forecast. The RMSE provides information on the short-term comparison of actual deviation between estimated and observed values of GSR. The evaluated values of statistical errors are

\begin{tabular}{|c|c|c|c|c|c|c|c|c|}
\hline \multirow[b]{2}{*}{ Models } & \multicolumn{4}{|c|}{ Empirical constants } & \multicolumn{4}{|c|}{ Statistical tools } \\
\hline & $\mathbf{a}$ & b & c & d & $\begin{array}{c}\text { MBE } \\
\left(\mathrm{MJ} / \mathrm{m}^{2} / \mathrm{day}\right)\end{array}$ & $\begin{array}{c}\text { RMSE } \\
\left(\mathrm{MJ} / \mathrm{m}^{2} / \mathrm{day}\right)\end{array}$ & $\begin{array}{c}\text { MPE } \\
(\%)\end{array}$ & $\mathbf{R}^{2}$ \\
\hline M-1 & 0.27 & 0.526 & & & 0.017 & 1.352 & 0.831 & 0.904 \\
\hline M-2 & 0.083 & 0.621 & & & -0.014 & 2.596 & 2.733 & 0.645 \\
\hline M-3 & 0.157 & 0.56 & 0.001 & & 0.02 & 1.337 & 0.817 & 0.906 \\
\hline M-4 & 0.253 & 0.51 & 0.003 & & 0.023 & 1.352 & 0.814 & 0.904 \\
\hline M-5 & 0.246 & 0.534 & 0.001 & & 0.042 & 1.35 & 0.821 & 0.904 \\
\hline M-6 & 0.247 & 0.495 & 0.055 & & 0.003 & 1.342 & 0.805 & 0.905 \\
\hline M-7 & 0.153 & 0.561 & 0.001 & 0.001 & 0.037 & 1.338 & 0.812 & 0.906 \\
\hline M-8 & 0.046 & 0.542 & 0.007 & 0.002 & 0.038 & 1.323 & 0.77 & 0.908 \\
\hline M-9 & 0.003 & 0.523 & 0.118 & 0.002 & -0.006 & 1.297 & 0.75 & 0.912 \\
\hline
\end{tabular}
summarized in Table 2.

Table 2: The empirical constants and statistical tools for different models for Lumle (optimal values are bold-faced)

According to the statistical test results, it is inferred that the estimated values of daily GSR are in agreement with the measured value of daily average GSR for all the models except model M-2 where 
the mean percentage error is highest $(2.733 \%)$ among the models. Even though all 9 models had nearly equal errors, model M-9 had the lowest value of MBE, RMSE, and MPE. Also as seen in Table 1, the coefficient of determination for all models achieved the result above 0.90 except the M-2 model. Furthermore, model M-9 had the highest value of the coefficient of determination 0.912. It is concluded that model M-9 was recommended to estimate daily average global solar radiation at Lumle, Nepal.

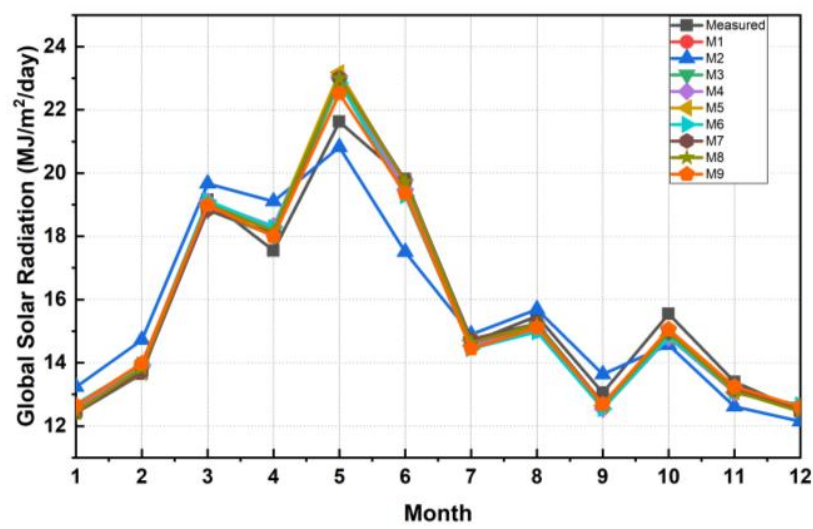

Fig. 2: Variation of measured monthly average daily global solar radiation and simulated radiation

The measured and estimated values of the monthly average daily GSR for all models were used for Lumle, it is shown in Fig. 2. In Table 1, the taking reference, there is less agreement between the values obtained from model M-2 with observed value, however, the remaining models have a better agreement. Therefore, the model M-9 was recommended for estimating daily average solar radiation at Lumle, Nepal.

GSR is highly affected by relative sunshine duration, temperature, and temperature difference. There is an increase in maximum temperature from January to the middle of the year and decreases at end of the year, but GSR does not follow temperature at the middle of the year due to cloud cover, heavy rainfall at that time. The temperature change in is directly affecting GSR at all months except January and December. However, GSR decreases with increases in relative humidity so it has anti-correlation with relative humidity. It is clearly shown in Fig. 4. This study site is a place where the highest rainfall occurs in Nepal. It means that GSR decreases with increases in rainfall and relative humidity. Especially, the GSR increases from January to March and then after it fluctuates of GSR due to the start of pre-monsoon. In the summer season, the temperature is higher, however, the GSR decreases with increases in heavy rainfall with thick clouds.

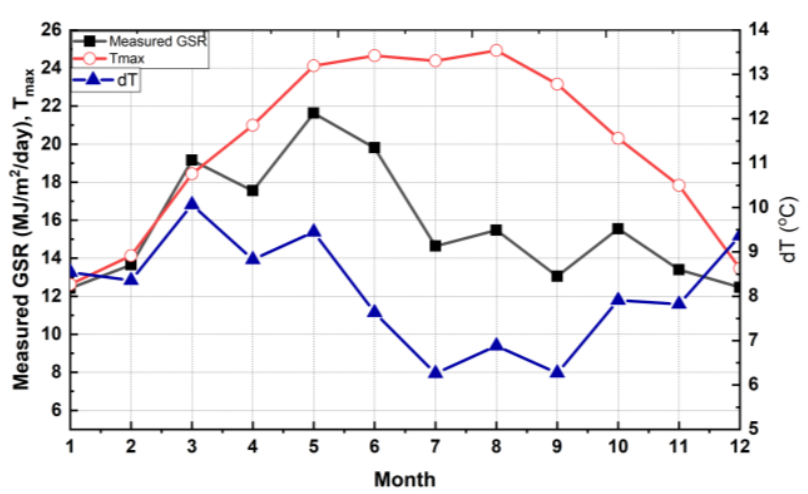

Fig.3: Variation of measured monthly global solar radiation, Tmax and difference between Tmax and $T_{\text {min }}$

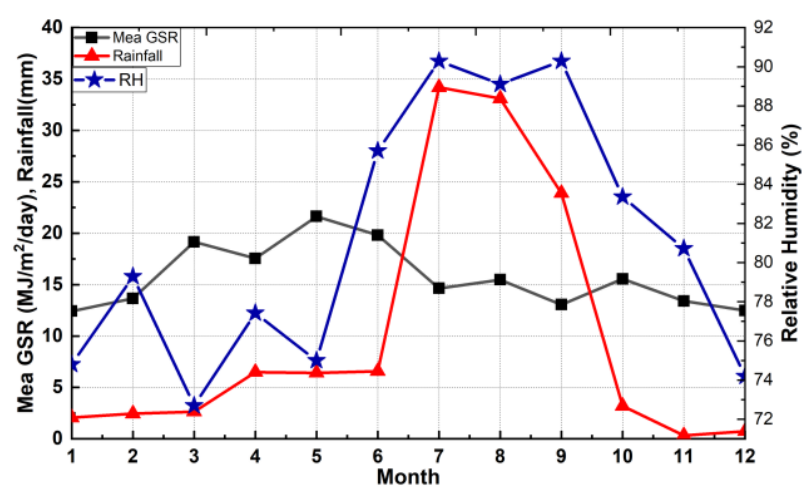

Fig.4: Variation of measured monthly global solar radiation, relative humidity and Rainfall

Thus, it has been shown that global solar radiation can be related to sunshine duration as well as temperature and relative humidity. The linear model with empirical constants $\mathrm{a}=0.003, \mathrm{~b}=0.523$, $c=0.118, d=0.0023$ are found respectively. Finally, it is recommended to estimate daily average global solar radiation for Lumle based on statistical results. The finding values of empirical constants can be used to predict GSR for similar geographical locations of Lumle. The yearly average GSR is obtained is $15.55 \mathrm{MJ} / \mathrm{m}^{2}$ per day and the yearly total GSR is $5676.85 \mathrm{MJ} / \mathrm{m}^{2}$ per day.

\section{CONCLUSION}

The objective of this study was to evaluate various models and also find the empirical constants which can be utilized for the estimation of the daily average global solar radiation on a horizontal 
surface. For the estimation of empirical constants of different models, the relative bright sunshine hour, temperature, and relative humidity were used by applying the linear regression technique for Lumle, Nepal. Finally, the different empirical constants were found which are utilized and tested at different models using different statistical tools. Comparing all different parameters of statistical tools, the Model M-9 was the best and its values of mean bias error (MBE), mean percentage error (MPE), root mean square error (RMSE) and coefficient of determination $\left(\mathrm{R}^{2}\right)$ were $-0.006,1.297$, 0.750 , and 0.912 respectively. Therefore, based on the statistical results a new simple multiple parameter model $\quad\left[\frac{H_{g}}{H_{o}}=0.003+0.523\left(\frac{n}{N}\right)+\right.$ $\left.0.118\left(\frac{\Delta T}{N}\right)+0.002(R H)\right]$ based on the modified Angstrom model is extremely recommended to estimate daily global solar radiation for the mid-hill region Lumle, Nepal. The empirical constants can be utilized at similar geographical conditions of Nepal. The annual average solar insolation of 4.32 $\mathrm{kWh} / \mathrm{m}^{2} /$ day was found in Lumle which is comparatively higher than in India (4.7 $\mathrm{kWh} / \mathrm{m}^{2} /$ day) [34] and China (2.5 -6.4 $\mathrm{kWh} / \mathrm{m}^{2} /$ day) [35]. So, it is confirmed that this amount of solar energy potential is significant to promote solar energy technology at the Lumle area.

\section{ACKNOWLEDGEMENT}

Authors would like to thank to faculty members and staffs of Dept. of Physics, Patan Multiple Campus, TU, Nepal and Applied Sciences, Chemical Engineering IOE, Pulchowk Campus, TU. Authors sincerely express deep gratitude to Alternate Energy Promotion Center (AEPC, GoV and World Bank for providing relevant meteorological data. We would like to thank NAST for providing partial financial support by $\mathrm{PhD}$ fellowship.

\section{REFERENCES}

[1] Iqbal, M. An introduction to solar radiation, Academic Press, New York, NY (1983).

[2] Poudyal, K. N. Estimation of Global Solar Radiation Potential in Nepal, Doctoral Thesis at IOE, Tribhuvan University (2015).

[3] Tarpley, J. Estimating incident solar radiation at the surface from geostationary satellite data, Journal of Applied Meteorology and Climatology, 18(9): 1172-81 (1979).

[4] Martinez-Lozano, J.; Tena, F.; Onrubia, J.; De La Rubia, J. The historical evolution of the
Ångström formula and its modifications: review and bibliography, Agricultural and forest meteorology, 33(2-3): 109-28 (1984).

[5] Liou, K. N. An introduction to atmospheric radiation, Elsevier (2002).

[6] Fraser, S.; Frase, P.; Butler J.; Connell, P.; Cunnold, D.; Daniel, J. et al. Controlled substances and other source gases. Chapter 1 in Scientific Assessment of Ozone Depletion: 2002, Global Ozone Research and Monitoring Project-Report No. 47, World Meteorological Organization, Geneva (2003).

[7] Water and Energy Commission Secretariat (WECS), Energy Commission Secretariat, Energy Sector Synopsis Report, Nepal Government of Nepal (2010).

[8] Poudyal, K.N.; Bhattarai, B. K.; Sapkota, B. K.; Kjeldstad, B. Estimation of global solar radiation using sunshine duration in Himalaya Region, Research Journal of chemical sciences, 2(11): 205 (2012).

[9] Adhikari, K. R.; Gurung, S.; Bhattarai, B. K. Solar energy potential in Nepal and global context, Journal of the Institute of Engineering, 9(1): 95-106 (2013).

[10] Olomiyesan, B.; Oyedum, O.; Ugwuoke, P.; Abolarin, M. Evaluation of Some Global Solar Radiation Models in Selected Locations in Northwest, Nigeria. Open Access Journal of Photo energy, 1(1): 1-6 (2017).

[11] Janjai, S.; Masiri, I.; Pattarapanitchai, S.; Laksanaboonsong, J. An Improved Model for the Estimation of Solar Radiation from Satellite Data for Thailand, Journal of the Institute of Engineering, 8(3): 130-9 (2011).

[12] Joshi, U.; Poudyal, K. N.; Karki, I. B.; Chapagain, N. P. Evaluation of Global Solar Radiation using Sunshine Hour, Temperature and Relative Humidity at Low Land Region of Nepal. Journal of Nepal Physical Society, 6(1): 16-24 (2020 Aug). Available from: https://www.nepjol.info/index.php/JNPhysSoc/article/view/30429.

[13] Angstrom, A. Solar and terrestrial radiation. Report to the international commission for solar research on actinometric investigations of solar and atmospheric radiation, Quarterly Journal of the Royal Meteorological Society, 50(210): 121-6 (1924).

[14] Prescott, J. A. Evaporation from a water surface in relation to solar radiation, Trans Roy Soc $S$ Aust, 46: 114-8 (1940).

[15] Bakirci, K. Correlations for estimation of daily global solar radiation with hours of bright sunshine in Turkey, 34(4): 485-501 (2009).

[16] Akinoglu, B.; Ecevit, A. Construction of a quadratic model using modified Ångstrom 
coefficients to estimate global solar radiation, Solar energy, 45(2): 85-92 (1990).

[17] Adhikari, K. R.; Bhattarai, B. K.; Gurung, S. et al. Estimation of global solar radiation for four selected sites in Nepal using sunshine hours, temperature and relative humidity, Journal of Power and Energy Engineering, 1(3): 1 (2013).

[18] Almorox, J.; Hontoria, C.; Benito, M. Models for obtaining daily global solar radiation with measured air temperature data in Madrid (Spain), Applied Energy, 88(5): 1703-9 (2011).

[19] Dhakal, S.; Gautam, Y.; Bhattarai, A. Evaluation of Temperature-Based Empirical Models and Machine Learning Techniques to Estimate Daily Global Solar Radiation at Biratnagar Airport, Nepal, Advances in Meteorology, 2020 (2020 Sep).

[20] Fletcher, A.; Moot, D. Estimating daily solar radiation in New Zealand using air temperatures, New Zealand Journal of Crop and Jorticultural Science, 35(1): 147-57 (2007).

[21] Poudyal, K. N.; Bhattarai, B. K.; Sapkota, B. K.; Kjeldstad, B.; Daponte, P. Estimation of the daily global solar radiation; Nepal experience, Measurement, 46(6): 1807-17 (2013).

[22] Glover, J.; McCulloch, J. The empirical relation between solar radiation and hours of sunshine, Quarterly Journal of the Royal Meteorological Society, 84(360): 172-5 (1958).

[23] Raja, I. A. Insolation-sunshine relation with site elevation and latitude, Solar Energy, 53(1): 53-6 (1994).

[24] Trabea, A.; Shaltout, M. M. Correlation of global solar radiation with meteorological parameters over Egypt, Renewable Energy, 21(2): 297-308 (2000).

[25] Alnaser, W. New model to estimate the solar global irradiation using astronomical and meteorological parameters, Renewable Energy, 3(2-3): 175-7 (1993).

[26] Rietveld, M. A new method for estimating the regression coefficients in the formula relating solar radiation to sunshine, Agricultural Meteorology, 19(2-3): 243-52 (1978).

[27] Kumar, R.; Umanand, L. Estimation of global radiation using clearness index model for sizing photovoltaic system, Renewable Energy, 30(15): 2221-33 (2005).

[28] Adhikari, K. R.; Gurung, S.; Bhattarai, B, K. Empirical model based on meteorological parameters to estimate the global solar radiation in Nepal, BIBECHANA, 11: 25-33 (2014).

[29] Joshi, U.; Karki, I. B.; Chapagain, N. P.; Poudyal, K. N. Prediction of daily global solar radiation using different empirical models on the basis of meteorological parameters at Trans Himalaya
Region, Nepal, BIBECHANA, 18(1): 159-69 (2021)

[30] Majupuria, T.; Kumar, R. Nepal, Nature's Paradise: Insight into Diverse Facets of Topography. Flora, and Ecology Gwalior, Nepal: Devi (1999).

[31] Survey Department, Government of Nepal. Map of Nepal, 2020. [Online; accessed 04-June-2021]. Available from: http://www.dos.gov.np/download/news-events/shapefilegis-data-forpolitical-and-administrative-map-of-nepal.

[32] The World bank, Nepal - Solar Radiation Measurement Data, Accessed: 2020-07-01, https://datacatalog.worldbank.org/.

[33] Duffie, J. A.; Beckman, W. A. Solar Engineering of Thermal Processes, 2nd edition, John Wiley and Sons, NewYork, NY (1991).

[34] Ministry of New and Renewable Energy, Government of India, SOLAR ENERGY, Accessed: 2021-05-02, https://mnre.gov.in/solar/current-status/.

[35] Wu, H.; Hou, Y. Recent development of gridconnected PV systems in China, Energy procedia, 12: $462-70$ (2011). 